\title{
Comparative study on gastrostomy and orally nutrition of children and adolescents with tetraparesis cerebral palsy
}

\author{
Thaisa Barboza CASELLI', Elizete Aparecida LOMAZI' ${ }^{1}$, Maria Augusta Santos MONTENEGRO² and \\ Maria Angela BELLOMO-BRANDÃO ${ }^{1}$
}

\begin{abstract}
Background - Gastrostomy tube feeding (GTF) is indicated for children with feeding difficulties due to tetraspastic cerebral palsy, although there are no definitive conclusions about the benefits of GTF. Objective - To compare nutritional status and diet of pediatric patients with tetraparesis cerebral palsy who are fed by GTF with those fed orally (PO). Methods - A transversal and descriptive study on 54 patients with spastic tetraparesis was held. The referred parameters were: weight, knee height and estimated height, cutaneous folds and circumferences. The Frisancho reference was used to compare the skin folds and body circumferences. The Brooks et al. curve was adopted as a reference for weight, height, and BMI. Food inquiry was performed using the Habitual Dietary Recall method. The total energetic value (TEV) of macronutrients and fibers was performed by Avanutri ${ }^{\circledR}$ version 4.0, a nutrition software program. The differences of nutritional parameters between the GTF and the PO groups were calculated by chi-squared and Fisher's exact tests, and the comparison between the groups for variable numbers was performed using the Mann-Whitney test. The significance level adopted was 5\%. Results - The PO group presented more individuals in the malnourished range (24.14\%) and high levels of adipose and thin mass depletion. The ingestion of lipids was larger in the GTF group, even though the proteins and fibers were higher in the PO group. The comparison between the diets in the GTF group indicated that the mixed diet (industrialized and artisanal) supplied a greater contribution of proteins and fibers. Conclusion-Comparing the groups, the tetraparesis cerebral palsy patients fed orally have a greater impairment of their nutritional status, even though they have higher intakes of protein and fiber than those patients fed by gastrostomy, demonstrating a consistent argument for the use of gastrostomy.
\end{abstract} HEADINGS - Cerebral palsy. Nutrition assessment. Gastrostomy. Malnutrition.

\section{INTRODUCTION}

Spastic tetraparesis, also known as tetraspastic cerebral palsy (TCP), corresponds to a set of non-progressive sequelae that affect the central nervous system $(\mathrm{CNS})^{(14)}$. In addition to the overall paralysis, it can cause convulsive syndromes and respiratory complications, and is considered the most severe form of the disease. Frequently, it is associated with dysfunctional feeding ${ }^{(11,21)}$

Postural changes caused by motor disorders provide inadequate performance of maintenance functions such as a lack of labial and an uncoordinated act of swallowing and breathing ${ }^{(27)}$. Thus, it is necessary that caregivers themselves regulate the food supply at ran$\mathrm{dom}^{(15)}$. Also, the presence of a swallowing disorder is frequent, which can contribute to growth retardation, malnutrition, and recurrent pulmonary aspiration leading to severe respiratory infections ${ }^{(8,13,25,26)}$.

The feeding difficulties may cause a reduction in the supply of energy and nutrients, leading to malnutrition and causing significant implications for overall development ${ }^{(10,15)}$. As a result, there is a depletion of body fat stores and muscle mass in addition to a dysfunctional immune system, resulting in increased morbidity/ mortality ${ }^{(7,19)}$. Thus, one of the biggest challenges in the care of patients with TCP is to provide an adequate dietary intake.
Gastrostomy tube feeding (GTF) has been indicated for children with difficulties in feeding due to the TCP in many countries, and it is considered a necessary, safe, and effective treatment ${ }^{(2)}$. The goal is to provide nutrition effectively and safely, enable increasing growth, reverse malnutrition, and improve general health ${ }^{(24)}$. However, Sleigh and Brocklehurst (2004) in their review concluded that there is little positive evidence on the effect of GTF. Although it was not possible to make definitive conclusions about the placement of gastrostomy or jejunostomy being beneficial or harmful, they raised important questions about the need for surgical procedures, serious complications, and increased risk of death ${ }^{(18)}$.

Enteral nutrition is often recommended in cases of dysfunctional feeding, reduction of food intake, and malnutrition. However, with the use of gastrostomy, delays are often observed in their recommendation and there is even resistance from the family ${ }^{(18)}$ because they fear the unknown and they need to understand that the benefits outweigh the risks of the procedure. This study was designed to compare the nutritional status and diet of children and adolescents with tetraspastic cerebral palsy (TCP) that were fed on enteral nutrition via GTF with those fed orally (PO).

Declared conflict of interest of all authors: none

Disclosure of funding: the project was funded by CAPES (01-P-4346-2015).

${ }^{1}$ Programa de Pós-Graduação em Saúde da Criança e do Adolescente, Departamento de Pediatria, Faculdade de Ciências Médicas, Universidade Estadual de Campinas, SP, Brasil; 2 Departamento de Neurologia, Faculdade de Ciências Médicas, Universidade Estadual de Campinas, SP, Brasil.

Correspondence: Thaisa Barboza Caselli. Avenida Juscelino Kubitschek de Oliveira, 1220 (Rua 6, número 50), Jardim Panorama - CEP: 15091450 - São José do Rio Preto, SP, Brasil. E-mail: thaisacaselli@gmail.com 


\section{METHODS}

The study was conducted in a tertiary university hospital with outpatients. It was approved by the Institutional Research Ethics Committee of the School of Medicine Science - University of Campinas/Brazil under the protocol no. 331.270 on July 10, 2013.

We evaluated 54 patients aged 2-19 years by a transversal, descriptive, and observational approach, divided into two groups: those fed by gastrostomy (GTF), at least for 6 months, and those fed orally (PO). All patients had definitive diagnosis of TCP, established by the Pediatric Neurology team. The patients using a nasogastric feeding tube and those with genetic diseases were excluded. Patients who had complains like fever, diarrhea, pneumonia, surgical complication during evaluation were excluded. General information, such as gender, age, and etiology of TCP, were obtained from medical records. The measurement of anthropometric variables was performed according to the following techniques and measures:

1) Knee height: with a caliper from Cescorf ${ }^{\circledR}$ and with the leg of the child at an angle of $90^{\circ}$, measuring the length of the anterior surface of the leg to the sole of the foot.

2) Estimated height: method used for patients unable to keep an orthostatic position for direct measurement of height. We used the knee value and applied it to specific mathematical formulas ${ }^{(4,20)}$.

3) Weight: measured by the difference between weight of the caregivers and the total weight of the children in the laps of those responsible (because of patients' inability to stand). A digital scale Filizola ${ }^{\circledR}$ was calibrated to zero for use.

4) Arm circumference (AC): the arm of the child was placed in a flexed position. The midpoint between the acromion and the olecranon was marked with non-elastic measuring tape. Thus, the arm circumference was measured with the pending member at the point marked.

5) Triceps skin folds (TSF): The Lange ${ }^{\circledR}$ caliper was applied to the back of the arm, at the same point used to obtain the AC.

The values of body mass index (BMI), arm muscle area (AMA), adipose arm area (AAA), and arm muscle circumference (AMB) were calculated using pre-established equations for these purposes.

The patients' weight, height and BMI were evaluated according to Brooks et al. (2011) reference curves ${ }^{(3)}$. As in the original study, those defined as malnourished had a weight for age index below the 25 th percentile. The Z-score was calculated also using the reference curves of the World Health Organization (WHO) ${ }^{(28)}$ with the following cuts: Eutrophic: Z-score $\geq-2 \mathrm{SD}$ and $\leq 1 \mathrm{SD}$; Malnourished: Z-score <-2SD; Obese: Z-score $>+2 \mathrm{SD}$. The values of folds and circumferences were compared with the Frisancho reference $(1993)^{(9)}$.

The feeding survey was performed with the Habitual Dietary Recall method. This food research was conducted by the researcher, according to the caregivers' reports. Patients using GTF were fed by industrialized, artisanal or mixed diet (industrialized + artisanal). The amounts were recorded as a household measure and subsequently transformed into grams $(\mathrm{g})$. The calculation of the total energy value (TEV), macronutrients (proteins, carbohydrates, lipids), and fibers was performed using the Avanutri ${ }^{\circledR}$ nutrition software version 4.0. The adequacy of intake was expressed in grams and percentages, and was compared with the nutritional recommendations of the Dietary Reference Intakes (DRI) $1997^{(12)}$.

Statistical analysis was performed with the Statistical Package for the Social Sciences ${ }^{\circledR}$ software (SPSS) version 17.0. The compari- son between groups for numerical variables was performed using the Mann-Whitney test. The difference of nutritional parameters between GTF and PO groups was calculated by chi-square test and Fisher's exact test. Significance level adopted was 5\%.

\section{RESULTS}

Twenty-five patients were fed by gastrostomy (GTF) and 29 orally (PO). Ages ranged from 2 years and 1 month to 18 years and 7 months, with a mean of 10.2 years \pm 4.45 and a median of 10.3 years. The PO group consisted of 18 male patients and 11 females, while in the GTF group there were 16 and 9, respectively.

Table 1 indicates differences between the groups for weight, height, and BMI of the curves according to Brooks et al. (2011) (3). Note that $24.1 \%$ of PO patients were found to be malnourished regarding weight and BMI. However, 21 patients fed orally were classified as eutrophic in all parameters compared with only 17 of the GTF group. These differences were not significant.

TABLE 1. Comparison between the gastrostomy and oral groups and the categorical variables weight, height and BMI according to the curves of Brooks et al. $(2011)^{(3)}$ and $P$-value of association tests between the variables

\begin{tabular}{|c|c|c|c|c|}
\hline Variables & $\begin{array}{l}\text { Feeding } \\
\text { method }\end{array}$ & $\mathbf{N}$ & Frequency (\%) & $P$ value \\
\hline \multirow{4}{*}{$\begin{array}{l}\text { Weight to age } \\
<\text { p25 }(n=12)\end{array}$} & & & & 0.0542 \\
\hline & & & & \\
\hline & GTF & 5 & 20.0 & \\
\hline & $\mathrm{PO}$ & 7 & 24.1 & \\
\hline \multicolumn{5}{|l|}{$\mathrm{p} 25-\mathrm{p} 90(\mathrm{n}=38)$} \\
\hline & GTF & 17 & 68.0 & \\
\hline & $\mathrm{PO}$ & 21 & 72.4 & \\
\hline \multicolumn{5}{|l|}{$>\mathrm{p} 90(\mathrm{n}=4)$} \\
\hline & GTF & 3 & 12.0 & \\
\hline & $\mathrm{PO}$ & 1 & 3.4 & \\
\hline \multirow{3}{*}{$\begin{array}{l}\text { Height to age } \\
\text { p10- >p90 }(\mathrm{n}=54)\end{array}$} & & & & None \\
\hline & & & & \\
\hline & $\begin{array}{l}\text { GTF } \\
\text { PO }\end{array}$ & $\begin{array}{l}25 \\
29\end{array}$ & $\begin{array}{c}10.0 \\
100.0\end{array}$ & \\
\hline \multirow{4}{*}{$\begin{array}{l}\text { BMI to age } \\
<\mathrm{p} 5(\mathrm{n}=12)\end{array}$} & & & & 0.088 \\
\hline & & & & \\
\hline & GTF & 5 & 20.0 & \\
\hline & $\mathrm{PO}$ & 7 & 24.1 & \\
\hline \multicolumn{5}{|l|}{ p10-p90 (n=39) } \\
\hline & GTF & 18 & 72.0 & \\
\hline & $\mathrm{PO}$ & 21 & 72.4 & \\
\hline \multicolumn{5}{|l|}{$>\mathrm{p} 90(\mathrm{n}=3)$} \\
\hline & GTF & 2 & 8.0 & \\
\hline & $\mathrm{PO}$ & 1 & 3.4 & \\
\hline
\end{tabular}

N: number of patients; BMI: body mass index; PO: orally; GTF: gastrostomy tube feeding. *Fisher's exact test.

In the comparison of the body composition between the groups, it was found that the GTF group had superior preservation of the adipose mass and lean mass according to TSF (64\%) and AC $(60 \%)$ parameters, as shown in Table 2. These differences were statistically significant. 
TABLE 2. Comparison between gastrostomy and oral groups and the categorical variables skinfold and arm circumferences and $P$-value of the association test between the variables

\begin{tabular}{|c|c|c|c|c|}
\hline Variables & $\begin{array}{l}\text { Feeding } \\
\text { method }\end{array}$ & $\mathbf{N}$ & $\begin{array}{c}\text { Frequency } \\
(\%)\end{array}$ & $P$ value \\
\hline \multirow[t]{3}{*}{$\begin{array}{l}C^{* *} \\
<\text { p5 e p5-p10 }(n=32)\end{array}$} & & & & $0.0075^{*}$ \\
\hline & GTF & 10 & 40.0 & \\
\hline & PO & 22 & 75.8 & \\
\hline \multicolumn{5}{|l|}{ p10-p90 e >p95 (n=22) } \\
\hline & GIF & 15 & 00.0 & \\
\hline \multirow{4}{*}{$\begin{array}{l}\text { TSF*** } \\
<\text { p5 e p5-p10 }(\mathrm{n}=21)\end{array}$} & $\mathrm{PO}$ & 7 & 24.1 & ค $\cap 01$ * \\
\hline & & & & \\
\hline & GTF & 3 & 12.0 & \\
\hline & $\mathrm{PO}$ & 18 & 62.7 & \\
\hline \multirow{3}{*}{$\mathrm{p} 10-90(\mathrm{n}=27)$} & & & & \\
\hline & GTF & 16 & 64.0 & \\
\hline & & & & \\
\hline \multicolumn{5}{|l|}{$>\mathrm{p} 95(\mathrm{n}=6)$} \\
\hline & GTF & 6 & 24.0 & \\
\hline \multirow{4}{*}{$\begin{array}{l}\text { AMC** } \\
<\text { p5 e p5-p10 (n=33) }\end{array}$} & $\mathrm{PO}$ & 0 & 0 & \\
\hline & & & & 0.2023 \\
\hline & GTF & 13 & 52.0 & \\
\hline & $\mathrm{PO}$ & 20 & 68.9 & \\
\hline \multicolumn{5}{|c|}{ p10-p90 e >p95 $(\mathrm{n}=21)$} \\
\hline & $\begin{array}{l}\text { GTF } \\
\text { PO }\end{array}$ & $\begin{array}{c}12 \\
9\end{array}$ & 48.0 & \\
\hline \multirow{3}{*}{$\begin{array}{l}\text { AMA } * * \\
<\text { p5 e p5-p10 }(\mathrm{n}=36)\end{array}$} & & & & 0.3346 \\
\hline & GTF & 15 & 60.0 & \\
\hline & PO & 21 & 72.4 & \\
\hline \multicolumn{5}{|c|}{ p10-p90 e >p95 (n=18) } \\
\hline & GTF & 10 & 40.0 & \\
\hline \multirow{3}{*}{$\begin{array}{l}\mathrm{AAA}^{*} * \\
<\mathrm{p} 5(\mathrm{n}=20)\end{array}$} & & 8 & & $0.003 *$ \\
\hline & GTF & 4 & 16.0 & \\
\hline & $\mathrm{PO}$ & 16 & 55.1 & \\
\hline \multirow[t]{2}{*}{$\mathrm{p} 10-95$ e $>$ p95 $(\mathrm{n}=34)$} & & & & \\
\hline & $\begin{array}{l}\text { GTF } \\
\text { PO }\end{array}$ & $\begin{array}{l}21 \\
13\end{array}$ & $\begin{array}{l}84.0 \\
83.0\end{array}$ & \\
\hline
\end{tabular}

$\mathrm{N}$ : number of patients; AC: arm circumference; TSF: triceps skin folds; AMC: arm muscle circumference; AMA: arm muscle area; AAA: adipose arm area; PO: orally; GTF: gastrostomy.

*There was a significant difference $P<0.05$ (chi-square test ** or Fisher's exact test ***).
Table 3 shows intake values of calories and nutrients. The intake of protein and fiber was higher in the PO group, while the GTF group had a higher intake of lipids. These differences were significant.

A comparative analysis between the diets used by the GTF group showed that the mixed diet (industrialized + artisanal) provides further respective quantities of protein and fiber $(17.11 \%$ and $10.65 \%)$ rather than of the industrialized $\operatorname{diet}(12.55 \%$ and $4.04 \%)$, which in turn provides an increased intake of lipids. These differences were statistically significant (Table 4).

\section{DISCUSSION}

The results of the present study showed that patients with spastic tetraparesis cerebral palsy orally fed have greater impairment of nutritional status than those who are fed by gastrostomy, despite having a higher food intake than the group with gastrostomy. In addition, we observed that the group with gastrostomy ingested less protein and fiber, according to the caregivers' report.

The available research concerning the use of gastrostomy on cerebral palsy patients indicate considerable heterogeneity, from tools used for evaluating to the different methods of recruitment, study duration, and outcomes analyzed. In the present study, we evaluated only patients with tetraspastic cerebral palsy, which is considered in the literature to be one of the most serious types of the disease

According to Brooks et al. curves (2011) ${ }^{(3)}$, there was no statistical difference for weight, height, and BMI between feeding types. However, when comparing body composition, there was a higher frequency of lean mass and fat preservation in GTF group.

Day et al. (2007) conducted a comparative study on patients with severe cerebral palsy (non-ambulant). They concluded that weight, height, and BMI of those fed by GTF were higher than those fed orally and, with the use of gastrostomy, there was a weight increase of $29 \%$ for males and $30 \%$ for females ${ }^{(6)}$. In addition, they reported that individuals who ate orally presented a greater and more severe impairment of nutritional status compared with those using GTF.

Regarding food consumption, the PO group showed a higher average intake of energy, carbohydrates, protein, and dietary fiber. When calculating daily energy needs, the literature considers that children with motor dysfunction must estimate about $11 \mathrm{kcal} / \mathrm{cm}^{(5)}$. Thus, the average calorie intake per day would be within the recommendation for the group, as well as the consumption of macronutrients. Sullivan et al. (2006) compared body composition

TABLE 3. Comparison of energy and macronutrient intake between gastrostomy and orally feeding groups

\begin{tabular}{|c|c|c|c|c|c|c|c|c|}
\hline Variables & Feeding method & $\mathbf{N}$ & Average & SD & Minimum & Median & Máximum & $P$ value \\
\hline \multirow[t]{3}{*}{ Energy (kcal) } & & & & & & & & \multirow[t]{3}{*}{0.8759} \\
\hline & GTF & 25 & 1234.9 & 359.3 & 548.0 & 1243.7 & 2311.2 & \\
\hline & $\mathrm{PO}$ & 29 & 1285.1 & 509.4 & 484.0 & 1243.4 & 2442.4 & \\
\hline \multirow{2}{*}{ Proteins (\%) } & GTF & 25 & 14.0 & 3.6 & 8.6 & 12.3 & 22.1 & \multirow{2}{*}{$0.0042 *$} \\
\hline & $\mathrm{PO}$ & 29 & 19.3 & 7.8 & 9.3 & 18.0 & 39.7 & \\
\hline \multirow{2}{*}{ Carbohydrates (\%) } & GTF & 25 & 55.2 & 4.4 & 48.1 & 53.2 & 65.9 & \multirow{2}{*}{0.4451} \\
\hline & $\mathrm{PO}$ & 29 & 56.5 & 10.2 & 33.4 & 54.6 & 84.9 & \\
\hline \multirow{2}{*}{ Lipids (\%) } & GTF & 25 & 31.1 & 5.9 & 19.0 & 30.9 & 41.8 & \multirow{2}{*}{$0.0008 *$} \\
\hline & $\mathrm{PO}$ & 29 & 24.1 & 7.9 & 5.7 & 22.1 & 40.0 & \\
\hline \multirow{2}{*}{ Fiber $(\mathrm{g})$} & GTF & 25 & 6.1 & 6.5 & 0 & 4.6 & 26.4 & \multirow{2}{*}{$0.0003 *$} \\
\hline & $\mathrm{PO}$ & 29 & 12.0 & 5.1 & 2.4 & 12.4 & 23.2 & \\
\hline
\end{tabular}

N: number of patients; SD: standard deviation; PO: orally; GTF: gastrostomy tube feeding. There were significant differences $* P<0.05$ (Mann-Whitney test). 
TABLE 4. Comparison of energy and macronutrient intake between the types of diets used by patients fed by gastrostomy

\begin{tabular}{|c|c|c|c|c|c|c|c|c|}
\hline Variables & Type of diet & $\mathbf{N}$ & Average & SD & Minimum & Median & Maximum & $P$ value \\
\hline \multirow[t]{2}{*}{ Energy (kcal) } & & & & & & & & 0.9304 \\
\hline & Industrialized & 17 & 1241.8 & 393.9 & 548.0 & 1243.7 & 2311.2 & \\
\hline \multirow[t]{2}{*}{ Proteins (\%) } & & & & & & & & $0.0154^{*}$ \\
\hline & Industrialized & 17 & 12.5 & 2.4 & 8.6 & 12.2 & 16.8 & \\
\hline \multirow[t]{3}{*}{ Carbohydrates (\%) } & & & & & & & & 0.1358 \\
\hline & Industrialized & 17 & 54.5 & 4.3 & 49.2 & 52.6 & 65.9 & \\
\hline & Mix & 8 & 56.5 & 4.7 & 4.7 & 57.5 & 64.1 & \\
\hline \multirow[t]{2}{*}{ Lipids (\%) } & & & & & & & & $0.0328 *$ \\
\hline & Industrialized & 17 & 32.9 & 5.8 & 21.8 & 34.7 & 41.8 & \\
\hline Fiber $(\mathrm{g})$ & Mix & 8 & 10.6 & 7.2 & 2.8 & 10.3 & 10.3 & \\
\hline
\end{tabular}

N: number of patients; SD: standard deviation; GTF: gastrostomy tube feeding. There were significant differences. $* P<0.05$ (Mann-Whitney test).

and energy balance of pediatric patients with spastic tetraparesis fed by GTF and PO. They reported that there was no statistically significant difference in the following parameters: lean mass and fat, weight, basal metabolic rate, and total energy expenditure, but considering that the more affected motor skills, the lower the muscle mass ${ }^{(22)}$. This may explain why children with GTF had lower total energy expenditure and therefore less demand for energy consumption than those fed orally, although this analysis was not statistically significant.

Fiber consumption reached the minimum recommendation of $5 \mathrm{~g}$ a day in both groups, but the GTF group consumed significantly less fiber than the PO group, which also occurred with protein intake.

The dietary assessment method known as Habitual Dietary Recall is considered useful and effective and is widely used for food intake analysis. However, it has limitations because it is based on the patient or family's report and depends on their memory to quantify the portions. The underestimation, overestimation, or concealment of portions and food interferes with dietary calculations ${ }^{(17)}$. Another factor is that many of the caregivers at the time of recall may have increased and enhanced the amount ingested by patients with fear of an indication for gastrostomy for the patient.

Sullivan et al. (2005) reported that while patients using GTF had a daily energy intake of $69 \%$ of the average estimated need, those who were exclusively fed PO reached only $57 \%$ of needs. They analyzed that after a full year diet usage via GTF there was an increase in energy consumption associated with an increase in the intake of lipids ${ }^{(23)}$.

Strauss et al. (1998) suggest that the feeding pathway has a major impact on the survival rate of children with TCP. Children fed by GTF had a higher risk of death compared with those who had some ability to "self-feed" and fed orally (hazard ratio $=23.65$ ). However, when they considered the degree of physical disability, the rate of death risks reduced, especially when the GTF was placed between the first two or three years of life (hazard ratio $=3.85$ ). Nevertheless, it is worth mentioning that children with TCP who have the capacity to feed themselves are not as weak as those who need a gastrostomy, which may help explaining the increased risk of death in this second group ${ }^{(21)}$.

The use of a homemade enteral diet is still very common in Brazil, however, there is an increase in the use of industrialized enteral formulas because they are considered more practical and safer from a microbiological point of view. Araújo and Menezes (2006) reported that it is possible to produce homemade enteral formulas using low cost conventional food and having an adequate nutritional composition ${ }^{(1)}$. Santos et al. (2013) also recommended the use of homemade diets as efficient alternatives in enteral nutrition therapy, provided that they are standardized and well directed for caregivers ${ }^{(16)}$.

However, in our study, the separated analysis of type of diet administred by gastrostomy has found that mixed diets provides a larger contribution of fiber than the industrialized diet. Sullivan et al. (2005) explained that enteral formulas should be enriched with fibers, since most cerebral palsy patients present constipation, and low dietary fiber intake is related to the presence of this comorbidity ${ }^{(23)}$.

Among gastrostomized patients, those fed with a mixed diet received more protein and fiber than those on exclusively industrialized diet. We strongly suggest an adequate supply of fiber for the care and prevention of constipation.

\section{ACKNOWLEDGMENT}

To the Espaço da Escrita / Coordenadoria Geral da UNICAMP for the contributions with the translation and CAPES or the financing of the project.

\section{Authors' contributions}

Caselli TB: lead researcher and article author. Lomazi EA: contribution with correction. Montenegro MAS: help in obtaining data. Bellomo-Brandão MA: project supervisor. 
Caselli TB, Lomazi EA, Montenegro MAS, Bellomo-Brandão MA. Estudo comparativo entre gastrostomia e alimentação via oral em crianças e adolescentes com paralisia cerebral tetraespástica. Arq Gastroenterol. 2017;54(4):292-6.

RESUMO - Contexto - A alimentação por gastrostomia é indicada para crianças com dificuldades de alimentação devido à paralisia cerebral tetraespástica, embora não haja conclusões definitivas sobre a colocação da alimentação por gastrostomia. Objetivo - Comparar o estado nutricional e dieta de crianças e adolescentes com paralisia cerebral tetraespástica alimentados via oral (VO) e via gastrostomia. Métodos - Estudo transversal e descritivo de 54 pacientes com paralisia cerebral tetraespástica. Os parâmetros aferidos foram: peso, altura do joelho e estatura estimada, dobras cutâneas e circunferências. Curvas de Brooks et al. foram adotadas como referência. O inquérito alimentar foi realizado pelo método Recordatório Alimentar Habitual. As diferenças dos parâmetros nutricionais entre os grupos Gastrostomia e VO foram calculadas por testes qui-quadrado e Exato de Fisher e a comparação entre os grupos para as variáveis numéricas foi realizada pelo teste de Mann-Whitney. O nível de significância adotado foi de 5\%. Resultados - O grupo alimentado via oral apresentou mais indivíduos na faixa da desnutrição (24,14\%) e maior depleção de massa magra e adiposa. A ingestão de lipídeos foi maior no grupo Gastrostomia, enquanto que de proteínas e de fibras foi superior no grupo VO. A comparação entre as dietas no grupo Gastrostomia indicou que a dieta mista (industrializada + artesanal) fornece maior aporte de proteínas e fibras. Conclusão-Os pacientes com paralisia cerebral tetraespástica alimentados por via oral têm um maior comprometimento do estado nutricional, mesmo que eles tenham um maior consumo de proteínas e fibras que os pacientes alimentados por gastrostomia, demonstrando um argumento consistente para o uso de gastrostomia.

DESCRITORES - Paralisia cerebral. Avaliação nutricional. Gastrostomia. Desnutrição.

\section{REFERENCES}

1. Araújo EM, Menezes HC. Formulações com alimentos convencionais para nutrição enteral ou oral. Ciênc. Tecnol. Aliment. 2006;26:533-8.

2. Bachrach S, Melnychuk JO, Vinton NE, Davis M, Shaffer S, Mehta D. Percutaneous endoscopic gastrostomy (PEG) tubes for enteral nutrition support (ENS) in neurologically impaired children. Dev Med Child Neurol (AACPDM Abstracts) 1998;40:16.

3. Brooks J, Day S, Shavelle R, Strauss D. Low weight, morbidity, and mortality in children with cerebral palsy: new clinical growth charts. Pediatrics. 2011;128:299-307.

4. Chumlea C, Guo SS, Steinbaugh ML. Prediction of stature from knee height for black and white adults and children with application to mobility-impared or Journal of the American Dietetic Association. 1994;94:1385-91.

5. Culley WJ, Middleton TO. Caloric requirements of mentally retarded children with and without motor dysfunction. J Pediatr. 1969;75:380-4.

6. Day SM, Strauss DJ, Vachon PJ, Rosenbloom L, Shavelle RM, Wu YW. Growth patterns in a population of children and adolescents with cerebral palsy. Develop Med Child Neurol. 2007;49:167-71.

7. De Onis M. Measuring nutritional status in relation to mortality. Bull of the World Health Organ. 2000; 78:1271-74.

8. Ferluga ED, Sathe NA, Krishnaswami S, Mcpheeters ML. Surgical intervention for feeding and nutrition difficulties in cerebral palsy: a sistematic review. Dev Med Child Neurol. 2014;56:31-43.

9. Frisancho AR. Anthropometric standards for the assessment of growth and nutrition status. Ann Arbor: University of Michigan Press; 1993.

10. Furkim AM, Behlau MS, Weckx LLM. Avaliação clínica e videofluoroscópica da deglutição em crianças com paralisia cerebral tetraparética espástica. Arq Neuro-psiquiatr. 2003;61:611-6.

11. Himmelmann K, Beckung E, Hagberg G, Uvebrant P. Gross and fine motor function and accompanying impairment in cerebral palsy. Dev Med Child Neurol. 2006;48:417-23

12. Institute of Medicine. Dietary reference intakes; the essential guide to nutriente requirements. Washington (DC): National Academy Press; 2006.

13. Koda YKL. Distúrbios da deglutição. In: Barbieri D, Koda YKL. Doenças gastroenterológicas em pediatria. São Paulo: Atheneu; 1996. p.77-81.

14. Koman LA, Smith BP, Shilt JS. Cerebral palsy. Lancet. 2004;363:1619-31.

15. Marchand V, Motil, K. NASPGHAN Comitee on Nutrition. Nutrition support for neurologically impaired children: a clinical report of the North American Society for Pediatric Gatroenterology, Hepatology, and Nutrition. J Pediatr Gastroenterol Nutr. 2006;43:123-35.
16. Santos VFN, Bottoni A, Morais TB. Qualidade nutricional e microbiológica de dietas enterais artesanais padronizadas preparadas nas residências de pacientes em terapia nutricional domiciliar. Rev Nutr. 2013;26:205-14.

17. Scagliusi FB, Lancha Júnior AH. Subnotificação da ingestão energética na avaliação do consumo alimentar. Rev Nutr. 2003;16:471-81.

18. Sleigh G, Brocklehurst P. Gastrostomy feeding in cerebral palsy: a systematic review. Arch Dis Child. 2004;89:534-9.

19. Stevenson RD, Conaway M, Chumlea WC, Rosenbaum P, Fung EB, Henderson $\mathrm{RC}$ et al. Growth and health in children with moderate-to-severe cerebral palsy. Pediatrics. 2006;118:1010-8.

20. Stevenson RD. Use of segmental measures to estimate stature in children with cerebral palsy. Arch Pediatr Adolesc Med. 1995;149:658-62.

21. Strauss DJ, Shavelle RM, Anderson TW. Life expectancy of children with cerebral palsy. Pediatr Neurol. 1998;18:143-9.

22. Sullivan PB, Alder N, Bachlet AME, Grant H, Juszczak E, Henry J et al. Gastrostomy feeding in cerebral palsy: too much of a good thing? Dev Med Child Neurol. 2006;48:877-82.

23. Sullivan PB, Juszczak E, Bachlet AM, Lambert B, Vernon-Roberts A, Grant HW et al. Gastrostomy tube feeding in children with cerebral palsy: a prospective, longitudinal study. Dev Med Child Neurol. 2005;47:77-85.

24. Sullivan PB, Morrice JS, Vernon-Roberts A, Grant H, Eltumi M, Thomas AG Does gastrostomy tube feeding in children with cerebral palsy increase the risk of respiratory morbidity? Arch Dis Child. 2006;91:478-82.

25. Tuchman DN. Disorders of deglution. In: Kleinman RE, Goulet OJ, Mieli-Vergani G, Sanderson IR, Sherman PM, Shneider BL. Walker's - Pediatric gastrointestinal disease: physiology, diagnosis and management. Shelton: People's Medical Publishing House; 2008. p.37-46.

26. Venkateswaran S, Shevell MI. Comorbidities and clinical determinants of outcome in children with spastic quadriplegic cerebral palsy. Dev Med Child Neurol. 2008;50:216-22.

27. Vivone GP, Tavares MMM, Bartolomeu RS, Nemr K, Chiappetta ALML. Análise da consistência alimentar e tempo de deglutição em crianças com paralisia cerebral tetraplégica espástica. Rev CEFAC. 2007;9:504-11.

28. World Health Organization. Management of severe malnutrition: a manual for physicians and other senior health workers. Geneva: WHO; 2000. 